\title{
Shredded beet pulp substituted for corn silage in diets fed to dairy cows under ambient heat stress: Feed intake, total-tract digestibility, plasma metabolites, and milk production
}

\author{
N. Naderi, ${ }^{*}$ G. R. Ghorbani, ${ }^{*}$ A. Sadeghi-Sefidmazgi, ${ }^{*}$ S. M. Nasrollahi, ${ }^{1}$ and K. A. Beauchemin $\ddagger$ \\ *Department of Animal Sciences, College of Agriculture, Isfahan University of Technology, Isfahan 84156-83111, Iran \\ †Department of Animal Sciences, College of Agriculture, Tehran University, Karaj, PO Box 3158711167-4111, Iran \\ łLethbridge Research and Development Centre, Agriculture and Agri-Food Canada, Lethbridge, AB, Canada T1J 4B1
}

\begin{abstract}
The effects of substituting increasing concentrations of dried, shredded beet pulp for corn silage on dry matter intake, nutrient digestibility, rumen fermentation, blood metabolites, and milk production of lactating dairy cows was evaluated under conditions of ambient heat stress. Four multiparous (126 $\pm 13 \mathrm{~d}$ in milk) and 4 primiparous ( $121 \pm 11 \mathrm{~d}$ in milk) Holstein cows were used in a $4 \times 4$ Latin square design experiment with 4 periods of $21 \mathrm{~d}$. Each period had $14 \mathrm{~d}$ of adaptation and $7 \mathrm{~d}$ of sampling, and parity was the square. Dietary treatments were (dry matter basis): $16 \%$ of dietary dry matter as corn silage without $\mathrm{BP}(0 \mathrm{BP}$, control diet); $8 \%$ corn silage and $8 \%$ beet pulp $(8 \mathrm{BP}) ; 4 \%$ corn silage and $12 \%$ beet pulp (12BP); and $0 \%$ corn silage and $16 \%$ beet pulp (16BP). Alfalfa hay was included in all diets (24\% dietary dry matter). Dietary concentrations of forage neutral detergent fiber and nonfiber carbohydrates were 21.3 and $39.2 \%$ (0BP), 16.5 and $40.9 \%$ (8BP), 14.1 and $42.2 \%$ (12BP), and 11.7 and $43.4 \%$ (16BP), respectively (dry matter basis). The ambient temperature-humidity index indicated that the cows were in heat stress for almost the entire duration of the study. Dry matter intake and nutrient digestibilities were similar across treatments and between multi- and primiparous cows. Mean rumen $\mathrm{pH}$ tended to decrease with increasing proportions of beet pulp in the diet. Also, increasing proportions of beet pulp in the diet linearly decreased acetate and butyrate concentrations in the rumen and increased propionate concentrations, leading to a linear decrease in acetate:propionate ratio. Milk yield linearly increased (38.5, 39.3, 40.9, and 39.6 $\mathrm{kg} / \mathrm{d}$ for $0 \mathrm{BP}, 8 \mathrm{BP}, 12 \mathrm{BP}$, and $16 \mathrm{BP}$, respectively), but fat content linearly decreased $(3.46,3.47,3.27$, and

Received February 12, 2016.

Accepted June 22, 2016.

${ }^{1}$ Corresponding author: smnasrolahi@gmail.com or smnasrolahi@ ut.ac.ir
\end{abstract}

2.99), such that we observed no effect on fat-corrected milk. Substituting beet pulp for corn silage increased the neutral detergent insoluble crude protein content of the diet, leading to a decrease in rumen concentration of ammonia-nitrogen and milk concentration of urea, corresponding to an increase in percentage of protein in milk. Compared with multiparous cows, primiparous cows had greater rumen $\mathrm{pH}$, metabolite concentrations in plasma (glucose, cholesterol, urea nitrogen, total protein, and globulins), milk production, and concentrations of milk components. Substituting beet pulp for corn silage at up to $12 \%$ of dietary dry matter can be beneficial during heat stress conditions.

Key words: beet pulp, corn silage, heat stress, dairy cow

\section{INTRODUCTION}

Feeding quality forage is crucial for maintaining the milk production and health of high-producing lactating dairy cows. However, producing high-quality forage is often costly and can be difficult to achieve due to unfavorable environmental growing and harvesting conditions. As a result, alternative non-forage fiber sources (NFFS) are included in dairy rations. These fiber sources are often byproducts of food processing, and their inclusion in ruminant diets provides an end use for these products, minimizing the agricultural land and water required for forage production.

In Iran, as in many parts of the world, sugar beets are the main feedstock used for sugar production, and dried, shredded beet pulp is a commonly available byproduct feedstuff. Beet pulp is high in NDF concentration (mean, $40.6 \%$ DM; range, 35.5 to $44.5 \%$; Naderi, 2014) and pectic substances (23\% DM; NRC, 2001). The NDF in beet pulp is digested more quickly than forage NDF (Bhatti and Firkins, 1995), and pectin is degraded more rapidly than cellulose and hemicellulose (Marounek et al., 1985). Pectin fermentation produces less lactate and propionate than starch fermentation and does not inhibit cellulose and hemicellulose diges- 
tion (Marounek et al., 1985). As a result, adding beet pulp to the diet of dairy cows may increase nutrient intake without negative effects on rumen health, leading to potential improvement in performance.

Ambient heat stress is an important problem for modern dairy farms in hot and humid climates. It depresses DMI and increases maintenance energy requirements due to the need to control body temperature (Moore et al., 2005; Liu et al., 2008; Baumgard and Rhoads, 2012). Replacing forages that require substantial eating and ruminating time with less bulky NFFS in the diet of dairy cows may improve intake, health, and productivity, but studies to confirm these potential improvements have been inconsistent (Penner et al., 2009; Miron et al., 2010; Zhang et al., 2010).

We hypothesized that substituting beet pulp for corn silage in the diet of dairy cows would increase DMI and milk production when cows were subjected to heat stress. The objective of this study was to investigate the effects of increasing the dietary concentration of beet pulp $(0,8,12$, and $16 \%$ of diet DM) at the expense of corn silage on the feed intake, nutrient digestibility, blood metabolites, and lactation performance of Holstein cows fed high-concentrate diets under conditions of heat stress.

\section{MATERIALS AND METHODS}

The experiment was conducted at the dairy facilities of the Lavark Research Station (Isfahan University of Technology, Isfahan, Iran). Animals were cared for according to the guidelines of the Iranian Council of Animal Care (1995), and the experiment was approved by the Institutional Animal Care Committee for Animals Used in Research.

\section{Animals, Experimental Design, and Treatments}

Four multiparous (BW $642 \pm 66 \mathrm{~kg}$; DIM $126 \pm$ $13 \mathrm{~d}$; milk yield $43 \pm 2 \mathrm{~kg} / \mathrm{d}$; all mean $\pm \mathrm{SE}$ ) and 4 primiparous (BW $504 \pm 39 \mathrm{~kg}$; DIM $121 \pm 11$ d; milk yield $41 \pm 4 \mathrm{~kg} / \mathrm{d}$; all mean $\pm \mathrm{SE}$ ) Holstein cows were used in a replicated $4 \times 4$ Latin square design with $21 \mathrm{~d}$ periods and parity as the square. Each period consisted of $14 \mathrm{~d}$ of adaptation followed by $7 \mathrm{~d}$ of data collection. Cows were housed in individual stalls $(4 \times$ $4 \mathrm{~m}$ ) in a roofed facility with open sides. Clean wood shavings and sand were used for bedding and refreshed daily. Four dietary treatments were evaluated: $0 \%$ beet pulp (0BP, control), $8 \%$ beet pulp (8BP), 12\% beet pulp (12BP), and $16 \%$ beet pulp (16BP), with beet pulp replacing corn silage in the diet on a DM basis. Diets were formulated to meet or exceed the Cornell Net Carbohydrate and Protein System (version 5.0; Fox et al., 2000) nutrient allowance for a lactating dairy cow weighing $650 \mathrm{~kg}$ and producing $45 \mathrm{~kg} / \mathrm{d}$ of milk with $3.0 \%$ milk true protein and $3.2 \%$ milk fat (Table 1). Feed was supplied twice daily at 0700 and $1800 \mathrm{~h}$ in amounts that allowed $10 \%$ refusal. Diets were manually mixed and weighed into each cow's feed trough, and refusals were manually removed each day and weighed. Of the daily allocation, $40 \%$ was given at the morning feeding, and $60 \%$ was given at the afternoon feeding.

\section{Environmental Measurements and Calculation of Temperature-Humidity Index}

The study was conducted from July 15, 2013, to September 6 , 2013. Ambient temperature $\left(\mathbf{T}_{\mathrm{db}},{ }^{\circ} \mathrm{C}\right)$ and relative humidity (RH, \%) were measured using a temperature and humidity data-logger (ST-172; Fotronic Co., Melrose, MA) at 15 min intervals over $24 \mathrm{~h}$ for 72 d (from d 12 of experiment until the end, every day) to calculate the temperature-humidity index (THI):

$$
\begin{aligned}
\mathrm{THI}= & \left(1.8 \times \mathrm{T}_{\mathrm{db}}+32\right)-[(0.55-0.0055 \times \mathrm{RH}) \\
& \left.\times\left(1.8 \times \mathrm{T}_{\mathrm{db}}-26.8\right)\right](\mathrm{NRC}, 1971) .
\end{aligned}
$$

\section{Intake, Digestibility, and Analyses}

The TMR amounts offered and refused were measured daily for each cow during the $7 \mathrm{~d}$ collection period, and daily DMI for each cow was calculated. Representative samples of forages (pooled within period), beet pulp (pooled within period), treatment TMR (pooled by diet within period), and individual refusals (pooled by cow within period) were taken immediately before the morning feeding during the $7 \mathrm{~d}$ collection period. All samples were immediately frozen at $-10^{\circ} \mathrm{C}$ until they were analyzed.

After thawing, the DM concentration of composited forages, beet pulp, TMR, and refusals samples was determined by drying at $60^{\circ} \mathrm{C}$ in a forced-air oven for $48 \mathrm{~h}$, and DM results were adjusted to $100^{\circ} \mathrm{C}$ according to AOAC International (2002; method 925.40). All samples were ground using a Wiley mill through a 1 mm screen (Arthur H. Thomas, Philadelphia, PA) and analyzed for CP using the Kjeldahl method (Kjeltec 1030 Auto Analyzer; Tecator, Höganäs, Sweden; AOAC International, 2002, method 955.04), ether extract (AOAC International, 2002, method 920.39), ash (AOAC International, 2002; method 942.05), and NDF using heat stable $\alpha$-amylase $(100 \mu \mathrm{L} / 0.5 \mathrm{~g}$ of sample, Van Soest et al., 1991). Neutral detergent insoluble crude protein (NDICP) and acid detergent insoluble crude protein (ADICP) were measured by analyzing the content of $\mathrm{CP}$ in $\mathrm{NDF}$ and $\mathrm{ADF}$, respectively. 
Non-fiber carbohydrate was calculated as $100-[\mathrm{CP}$ $+(\mathrm{NDF}-\mathrm{NDICP})+$ ether extract + ash]. Soluble protein was measured as the amount of $\mathrm{CP}$ soluble in borate buffer, and NPN was calculated as the difference between soluble protein and true protein precipitated in trichloroacetic acid (Licitra et al., 1996).

Refusals from individual cows were used to calculate nutrient intake. Sample TMR and feces taken from each cow after the morning feeding on d 16 to 21 of each period were pooled and analyzed for acid-insoluble ash as an internal marker to calculate apparent digestibility using the $2 \mathrm{~N} \mathrm{HCl}$ procedure of Van Keulen and Young (1977).

\section{Rumen Sampling and Analysis}

On d 21 of each period, $4 \mathrm{~h}$ after the morning feeding, rumen fluid (about $3 \mathrm{~mL}$ ) was sampled from the ventral sac via rumenocentesis, the technique developed by Nordlund and Garrett (1994). The pH of the ruminal fluid was immediately determined using a portable digital pH meter (HI 8318; Hanna Instruments, ClujNapoca, Romania), and samples were immediately frozen at $-18^{\circ} \mathrm{C}$. Upon thawing at room temperature (i.e., $20^{\circ} \mathrm{C}$ ), ruminal fluid was prepared for VFA analysis by gas chromatography (Chrompack, model CP-9002; Chrompack International BV, Middelburg, the Nether-

Table 1. Ingredients and chemical composition (\% of DM; SD in parentheses) of the experimental diets on a DM basis

\begin{tabular}{|c|c|c|c|c|}
\hline \multirow[b]{2}{*}{ Item } & \multicolumn{4}{|c|}{$\operatorname{Diet}^{1}$} \\
\hline & $0 \mathrm{BP}$ & $8 \mathrm{BP}$ & $12 \mathrm{BP}$ & $16 \mathrm{BP}$ \\
\hline \multicolumn{5}{|c|}{ Ingredient composition, $\%$ of DM } \\
\hline Alfalfa hay & 24.05 & 24.05 & 24.05 & 24.05 \\
\hline Corn silage & 16.04 & 8.02 & 4.01 & 0.00 \\
\hline Beet pulp & 0.00 & 8.02 & 12.03 & 16.04 \\
\hline Corn grain, ground & 20.45 & 20.45 & 20.45 & 20.45 \\
\hline Barley grain, ground & 18.44 & 18.44 & 18.44 & 18.44 \\
\hline Soybean meal, pelleted & 10.44 & 10.44 & 10.44 & 10.44 \\
\hline Yasmino-max ${ }^{2}$ & 2.61 & 2.61 & 2.61 & 2.61 \\
\hline Corn gluten meal & 2.16 & 2.16 & 2.16 & 2.16 \\
\hline Fat powder ${ }^{3}$ & 2.81 & 2.81 & 2.81 & 2.81 \\
\hline Sodium bicarbonate & 1.00 & 1.00 & 1.00 & 1.00 \\
\hline Calcium carbonate & 0.38 & 0.38 & 0.38 & 0.38 \\
\hline Calcium phosphate (mono) & 0.42 & 0.42 & 0.42 & 0.42 \\
\hline Vitamin-mineral premix ${ }^{4}$ & 1.00 & 1.00 & 1.00 & 1.00 \\
\hline Salt & 0.20 & 0.20 & 0.20 & 0.20 \\
\hline \multicolumn{5}{|l|}{ Chemical composition } \\
\hline DM, \% of as fed & $59.2(2.21)$ & $58.8(0.51)$ & $59.1(0.60)$ & $58.5(2.30)$ \\
\hline $\mathrm{OM}$ & $92.2(0.33)$ & $92.1(0.59)$ & $92.0(0.32)$ & $91.9(0.59)$ \\
\hline $\mathrm{CP}$ & $16.3(0.83)$ & $16.5(0.28)$ & $16.6(0.71)$ & $16.7(0.44)$ \\
\hline $\mathrm{SP},{ }^{5} \%$ of $\mathrm{CP}$ & $20.2(0.86)$ & $19.6(0.68)$ & $19.0(0.62)$ & $18.56(0.41)$ \\
\hline $\mathrm{NPN}, \%$ of $\mathrm{CP}$ & $18.2(0.32)$ & $17.3(0.30)$ & $16.6(0.20)$ & $16.1(0.85)$ \\
\hline NDICP,${ }^{5} \%$ of CP & $13.5(1.80)$ & $17.0(1.62)$ & $21.0(1.25)$ & $23.7(0.52)$ \\
\hline $\mathrm{ADICP},{ }^{5} \%$ of $\mathrm{CP}$ & $4.1(0.28)$ & $4.5(0.78)$ & $4.9(0.58)$ & $5.3(0.98)$ \\
\hline $\mathrm{NDF}$ & $33.6(0.99)$ & $32.4(1.44)$ & $31.8(0.87)$ & $31.0(1.12)$ \\
\hline Forage NDF & 21.3 & 16.5 & 14.1 & 11.7 \\
\hline $\mathrm{ADF}$ & $19.8(1.37)$ & $17.9(0.94)$ & $16.8(1.31)$ & $15.9(1.48)$ \\
\hline $\mathrm{NFC}^{6}$ & $39.2(1.48)$ & $40.9(2.46)$ & $42.2(1.43)$ & $43.4(2.31)$ \\
\hline Ether extract & $5.2(0.30)$ & $5.0(0.23)$ & $4.9(0.29)$ & $4.80(0.21)$ \\
\hline Ash & $7.8(0.33)$ & $7.9(0.59)$ & $8.0(0.32)$ & $8.1(0.59)$ \\
\hline NFC:NDF ratio & 1.17 & 1.26 & 1.33 & 1.4 \\
\hline $\mathrm{NE}_{\mathrm{L}},{ }^{7} \mathrm{Mcal} / \mathrm{kg}$ of DM & 1.66 & 1.70 & 1.71 & 1.73 \\
\hline
\end{tabular}

${ }^{1}$ Experimental diets were beet pulp (BP) substituted for corn silage as 0, 8, 12, and $16 \%$ of diet DM.

${ }^{2}$ Yasna-Mehr Co., Tehran, Iran.

${ }^{3}$ Containing fatty acids including C12:0 (2 g/100 g of fatty acids), C14:0 (5 g/100 g of fatty acids), C16:0 (80 $\mathrm{g} / 100 \mathrm{~g}$ of fatty acids), C18:0 (2 g/100 g of fatty acids), C18:1 (7 g/100 g fatty acids), and C18:2 $(3 \mathrm{~g} / 100 \mathrm{~g}$ of fatty acids).

${ }^{4}$ Containing (DM basis) 1,300,000 IU $/ \mathrm{kg}$ of vitamin $\mathrm{A} ; 360,000 \mathrm{IU} / \mathrm{kg}$ of vitamin $\mathrm{D}_{3} ; 12,000 \mathrm{IU} / \mathrm{kg}$ of vitamin $\mathrm{E} ; 10 \mathrm{~g} / \mathrm{kg}$ of manganese; $16 \mathrm{~g} / \mathrm{kg}$ of zinc; $4 \mathrm{~g} / \mathrm{kg}$ of copper; $0.15 \mathrm{~g} / \mathrm{kg}$ of iodine; $0.12 \mathrm{~g} / \mathrm{kg}$ of cobalt; $0.8 \mathrm{~g} / \mathrm{kg}$ of iron; and $0.08 \mathrm{mg} / \mathrm{kg}$ of selenium.

${ }^{5} \mathrm{SP}=$ soluble protein in borate buffer; NDICP $=$ neutral detergent insoluble $\mathrm{CP} ; \mathrm{ADICP}=$ acid detergent insoluble CP; Licitra et al. (1996).

${ }^{6} \mathrm{NFC}=100-[\mathrm{CP}+(\mathrm{NDF}-\mathrm{NDICP})+$ fat + ash $]$.

${ }^{7}$ Based on tabular values (Cornell Net Carbohydrate and Protein System; Fox et al., 2000). 
lands) using a 50-m (0.32 mm i.d.) fused-silica column (CP-Wax Chrompack Capillary Column; Varian Inc., Palo Alto, CA), and crotonic acid as the internal standard. Nitrogen was used as carrier gas, and oven initial and final temperatures were 55 and $195^{\circ} \mathrm{C}$, respectively. Detector and injector temperatures were set at $250^{\circ} \mathrm{C}$. Ruminal ammonia-nitrogen $\left(\mathrm{NH}_{3}-\mathrm{N}\right)$ concentration was determined using the colorimetric phenol-hypochlorite method of Broderick and Kang (1980).

\section{Blood Sampling and Analyses}

On d 20 of each period, blood samples $(7 \mathrm{~mL})$ were collected $3 \mathrm{~h}$ after the morning feeding via the coccygeal vein using evacuated tubes with anticoagulant (EDTA). Blood samples were placed on ice immediately after collection and centrifuged at $3,000 \times g$ for 15 min. Plasma samples were separated and stored frozen in plastic tubes at $-20^{\circ} \mathrm{C}$ until analysis. Commercial kits (Pars Azmoon Co., Tehran, Iran) were used to measure concentrations of glucose (glucose oxidasephenol 4-aminoantipyrine peroxidase method, kit number 1500017), triglycerides (glycerol-3-phosphate oxidase-phenol 4-aminoantipyrine peroxidase method, kit number 1500032), total protein (biuret method, kit number 1500028), albumin (bromocresol green method, kit number 1500001), urea nitrogen (Berthelot method, kit number 1400030), cholesterol (cholesterol oxidasephenol 4-aminoantipyrine peroxidase method, kit number 1500010), and uric acid (enzymatic colorimetric uricase method, kit number 1400031) were measured using commercial kits (Pars Azmoon Co.) according to the manufacturer's instructions. Globulin concentrations were obtained by subtracting albumin from total protein. Plasma concentrations of BHB were determined using a commercial colorimetric kit (kit number RB1007; Randox Laboratories Ltd., Ardmore, UK).

\section{Milk Yield and Components, BW, and BCS}

Cows were milked 3 times daily at 0100, 0900, and $1700 \mathrm{~h}$ in a herringbone milking parlor. Milk yield for all cows was recorded and sampled at each milking during the final $5 \mathrm{~d}$ of each period. Milk samples were composited in proportion to milk yield, preserved with potassium dichromate, stored at $4^{\circ} \mathrm{C}$, and submitted to the Isfahan University of Technology Central Milk Testing Laboratory (Isfahan, Iran) for fat, protein, and lactose analyses using an infrared analyzer (MilkoScan 134 BN; Foss Electric, Hillerød, Denmark; AOAC International, 2002; method 972.16). The MUN content was also determined by enzymatic assay (Wilson et al., 1998). Milk was centrifuged at 1,200 $\times g$, and the fat was removed. The defatted milk was then thoroughly mixed and deproteinized by mixing $0.2 \mathrm{~mL}$ of defatted milk with $1.8 \mathrm{~mL}$ of cold trichloroacetic acid and allowing the mixture to stand for $5 \mathrm{~min}$. The sample was then centrifuged at $1,200 \times g$ for $5 \mathrm{~min}$ at $20^{\circ} \mathrm{C}$, and $0.2 \mathrm{~mL}$ of the clear supernatant was analyzed for MUN using a colorimetric diacetyl monoxime procedure.

The yield of 3.5\% FCM, ECM, and solids-corrected milk (SCM) were calculated according to NRC (2001) equations:

$$
\begin{aligned}
& \mathrm{FCM}=0.432 \times \text { milk yield }+16.23 \times \text { fat yield }, \\
& \begin{aligned}
\mathrm{ECM}= & 12.82 \times \text { fat yield }+7.13 \times \text { protein yield } \\
& +0.323 \times \text { milk yield }, \\
\mathrm{SCM}= & \text { milk yield } \times[(12.24 \times \text { fat } \% \times 0.01) \\
& +(7.1 \times \text { protein } \% \times 0.01) \\
+ & (6.35 \times \text { lactose } \% \times 0.01)-0.0345] .
\end{aligned}
\end{aligned}
$$

Cows were weighed at the end of each period, and BCS was determined using a 5-point scale, where $1=$ emaciated and $5=$ obese (Ferguson et al., 1994). Also at the end of each experimental period, back fat thickness was measured using a portable B-mode ultrasound generator (SonoVet 600V; BCF Technology Ltd., West Lothian, UK) with a linear transducer and frequency between 5.0 and $6.5 \mathrm{MHz}$ (Kargar et al., 2013).

\section{Statistical Analyses}

Data were summarized by period and analyzed using the mixed model procedure in SAS (SAS Institute, 2003) to account for the fixed effects of square (parity), period within square, cow within square, and diet. Cow within square was the specified term for the random effect. The restricted maximum likelihood method was used to estimate LSM, and the Kenward-Roger method was used to calculate denominator degrees of freedom. The statistical model used for analyses was

$$
\mathrm{Y}_{\mathrm{ij}(\mathrm{k}) \mathrm{m}}=\mu+\mathrm{S}_{\mathrm{m}}+\mathrm{P}(\mathrm{S})_{\mathrm{im}}+\mathrm{A}(\mathrm{S})_{\mathrm{jm}}+\mathrm{T}_{\mathrm{k}}+\mathrm{e}_{\mathrm{ij}(\mathrm{k}) \mathrm{m},}
$$

where $Y_{\mathrm{ij}(\mathrm{k}) \mathrm{m}}$ was each observation, $\mu$ was the overall mean, $\mathrm{S}_{\mathrm{m}}$ was the fixed effect of square $\mathrm{m}, \mathrm{P}(\mathrm{S})_{\text {im }}$ was the fixed effect of period i within square $\mathrm{m}, \mathrm{A}(\mathrm{S})_{\mathrm{jm}}$ was the random effect of cow $j$ within square $m, T_{k}$ was the fixed effect of treatment $\mathrm{k}$, and $\mathrm{e}_{\mathrm{ij}(\mathrm{k}) \mathrm{m}}$ was residual. The interaction between treatment and square (parity) was also included in the model, and the interaction was identified in the results and tables when significant; otherwise, it was dropped from the model. 
Polynomial orthogonal contrasts were used to test the linear, quadratic, and cubic effects of increasing proportions of beet pulp. The cubic effect was not significant for any variable unless reported. The differences among the treatments were evaluated using a multiple comparison test following the Tukey-Kramer method. Statistical significance of main effects was declared at $P \leq 0.05$, and tendencies were discussed at $0.05 \leq P \leq 0.10$.

\section{RESULTS}

\section{Diet Characteristics}

The ingredient composition and chemical analysis of experimental TMR are presented in Table 1. Numerically greater $\mathrm{CP}, \mathrm{NFC}, \mathrm{NDICP}, \mathrm{ADICP}$, and $\mathrm{NE}_{\mathrm{L}}$ concentrations and lower NDF, ADF, forage NDF, SP, NPN, and ether extract concentrations with increasing beet pulp in the diet reflected differences in the chemical composition of beet pulp and corn silage (Table 2).

\section{Ambient Temperature-Humidity Index}

The average daily THI data indicated that the cows were experiencing heat stress (THI >68; Armstrong, 1994; Bernabucci et al., 2010) during almost the entire experiment, with a value exceeding 70 units on most days (Figure 1). Moreover, the THI exceeded 68 units on average for $19 \mathrm{~h} / \mathrm{d}, 70$ units for $16 \mathrm{~h} / \mathrm{d}$, and 72 units for $13 \mathrm{~h} / \mathrm{d}$.

\section{Nutrient Intake and Digestibility}

The DMI was similar across dietary treatments and between multiparous and primiparous cows (Table 3). Substituting beet pulp for corn silage did not affect apparent the digestibilities of DM, OM, NDF, or ADF and we observed no difference in digestibility between multi- and primiparous cows.

\section{Rumen Fermentation}

Mean rumen $\mathrm{pH}$ tended to decrease with increasing beet pulp proportion in the $\operatorname{diet}(P=0.08$; Table 4$)$. Multiparous cows had lower ruminal $\mathrm{pH}$ than primiparous cows (5.95 vs. $6.22 ; P=0.01$ ). Although total VFA concentration in the rumen was not affected by diet, proportions of individual VFA differed. Increasing beet pulp in the diet quadratically affected acetate concentration $(P=0.01)$. Concurrently, propionate concentration increased linearly with increased substitution of beet pulp for corn silage, whereas butyrate and valerate concentrations and acetate:propionate ratio decreased linearly (Table 4. Total VFA concentration in the rumen tended $(P=0.08)$ to be greater for multiparous cows; they had higher propionate and valerate concentrations and lower acetate, butyrate and valerate concentrations, as well as a lower acetate:propionate ratio in the rumen $(P<0.01)$. The ruminal $\mathrm{NH}_{3}-\mathrm{N}$ concentration also decreased linearly as corn silage was replaced with beet pulp $(P<0.01)$, but this finding was not affected by parity.

Table 2. Chemical composition (\% of DM, unless otherwise noted) of corn silage and beet pulp

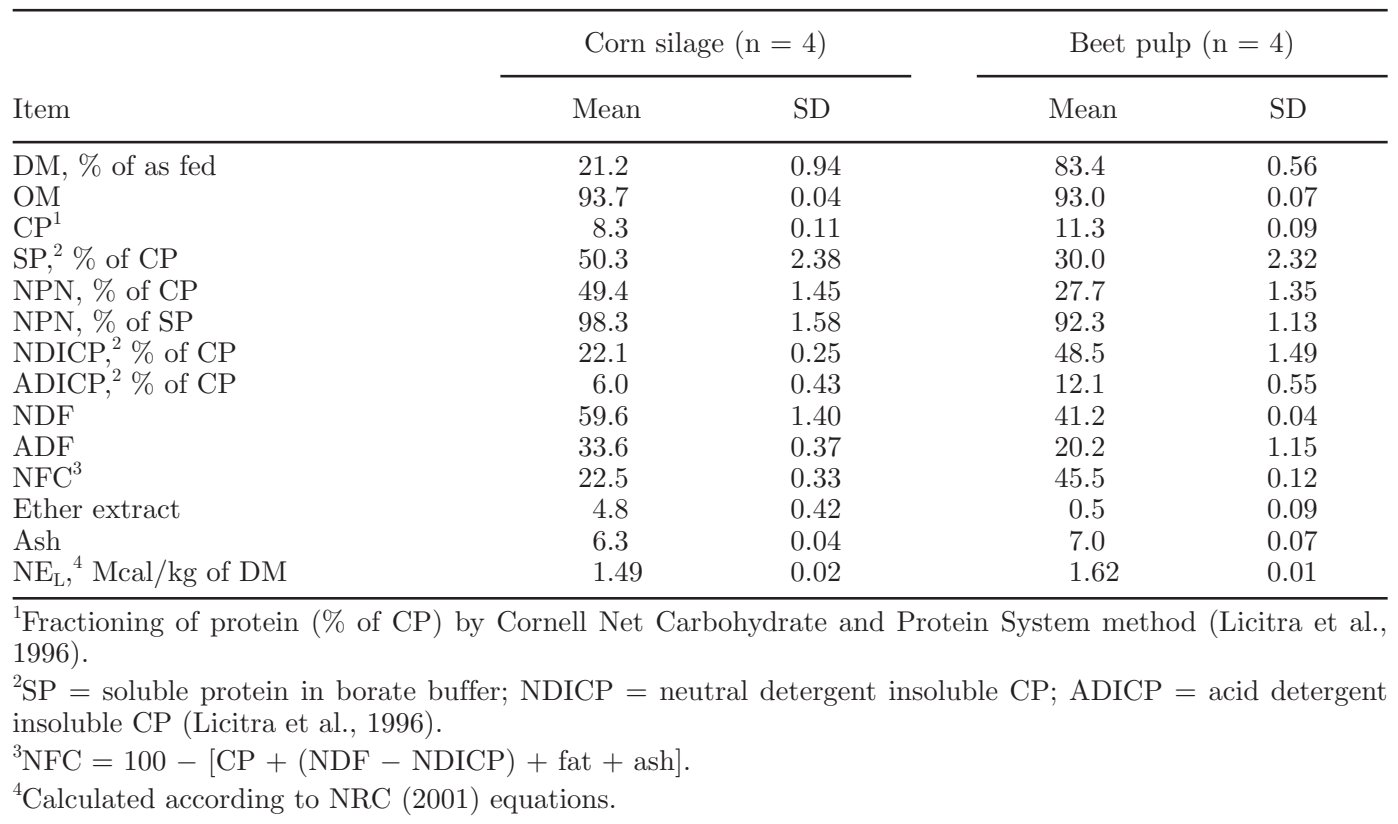




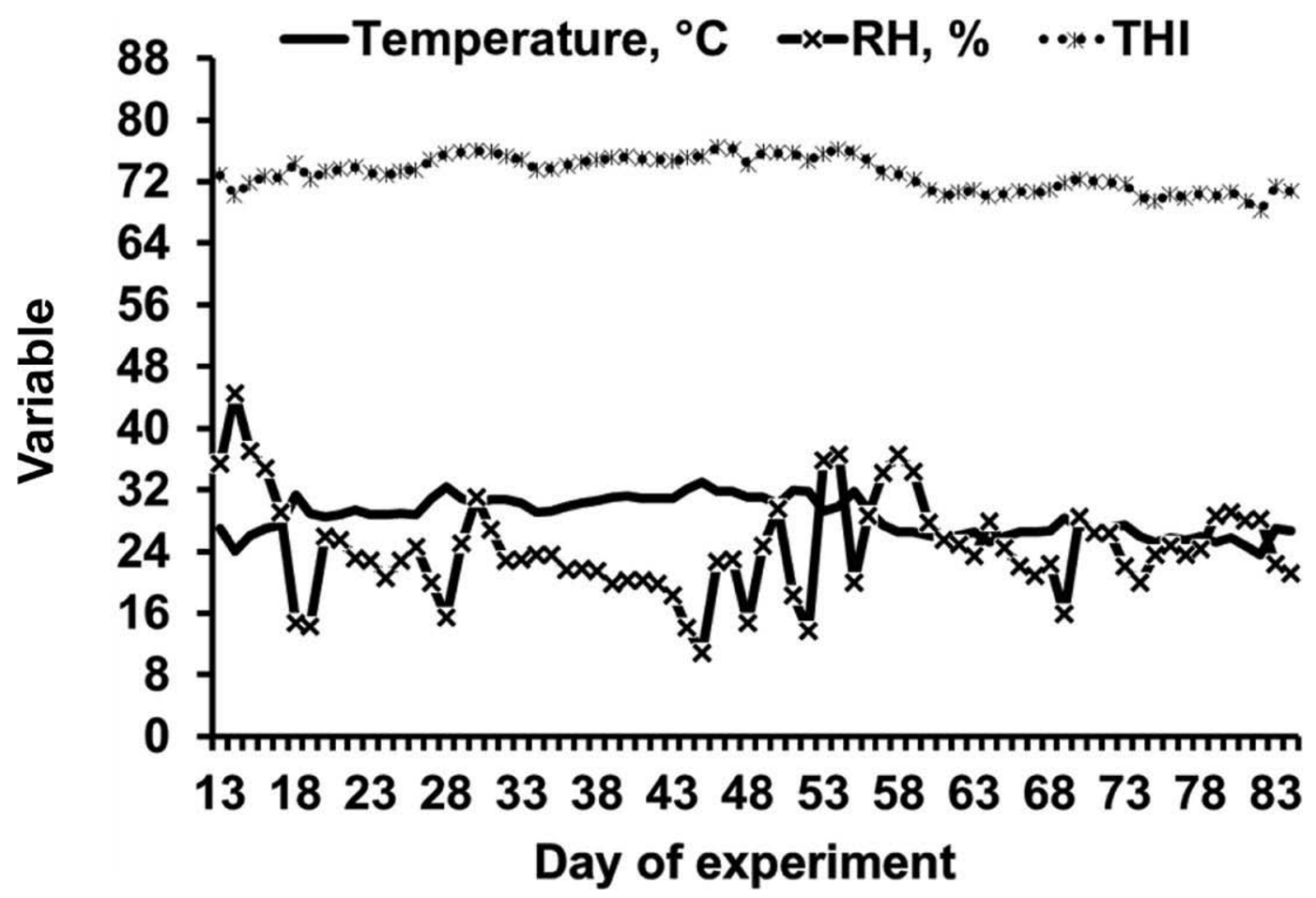

Figure 1. Change in temperature, relative humidity $(\mathrm{RH})$, and temperature-humidity index (THI) during the experiment. The study was conducted between July 15, 2013, and September 6, 2013.

\section{Plasma}

Substitution of beet pulp for corn silage did not affect plasma concentrations of glucose, cholesterol, triglyceride, or urea nitrogen (Table 5). However, BHB concentrations decreased linearly as beet pulp increased in the diet $(P<0.01)$. Multiparous cows had lower plasma glucose $(P=0.03)$ and cholesterol $(P<0.01)$ concentrations than primiparous cows, but triglyceride and BHB concentrations were similar. Protein-related variables (i.e., albumin, globulin, total protein, and albumin:globulin ratio) were similar across diets. Compared with multiparous cows, primiparous cows had lower plasma urea nitrogen $(P=0.03)$, globulin $(P=$ $0.02)$, and total protein $(P=0.03)$.

\section{Milk Yield and Milk Composition}

Substitution of beet pulp for corn silage linearly increased milk yield up to 12BP, but there was no further increase at $16 \mathrm{BP}(P=0.03$; Table 6$)$. The response of $3.5 \%$ FCM, ECM, and SCM tended $(P=0.06)$ to be quadratic with increasing dietary beet pulp levels, and milk fat production was quadratically $(P=0.05)$ affected because of changes in milk yield and fat concentration. Milk fat percentage decreased linearly $(P$ $<0.01$ ), and was significantly lower for 16BP than for control (2.99 vs. $3.46 \% ; P=0.02)$. Protein concentration increased linearly $(P=0.05)$ with increasing beet pulp levels, but lactose concentration was not affected by diet. The fat:protein ratio was lowest with the great-

Table 3. Effect of substitution of beet pulp for corn silage on nutrient intake and apparent digestibility of nutrients

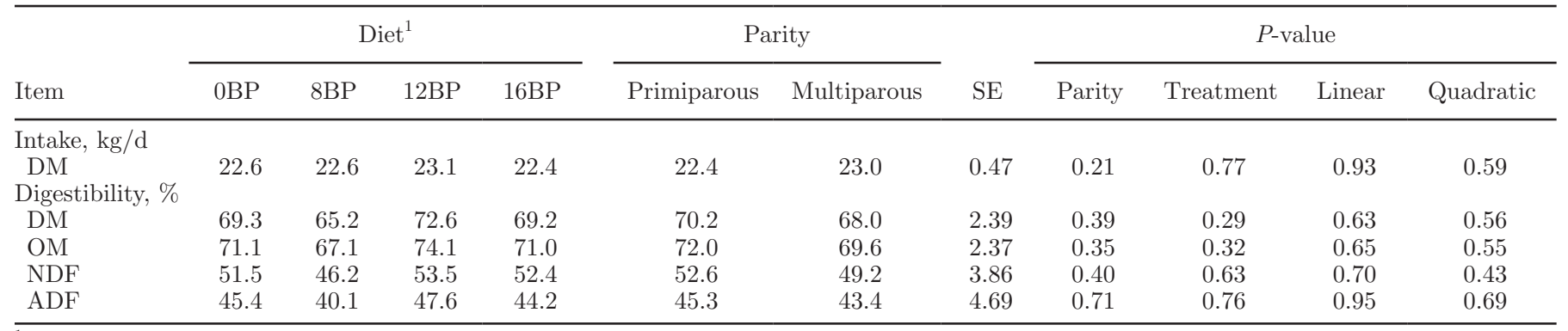

${ }^{1}$ Experimental diets were beet pulp (BP) substituted for corn silage as $0,8,12$, and $16 \%$ of diet DM. 

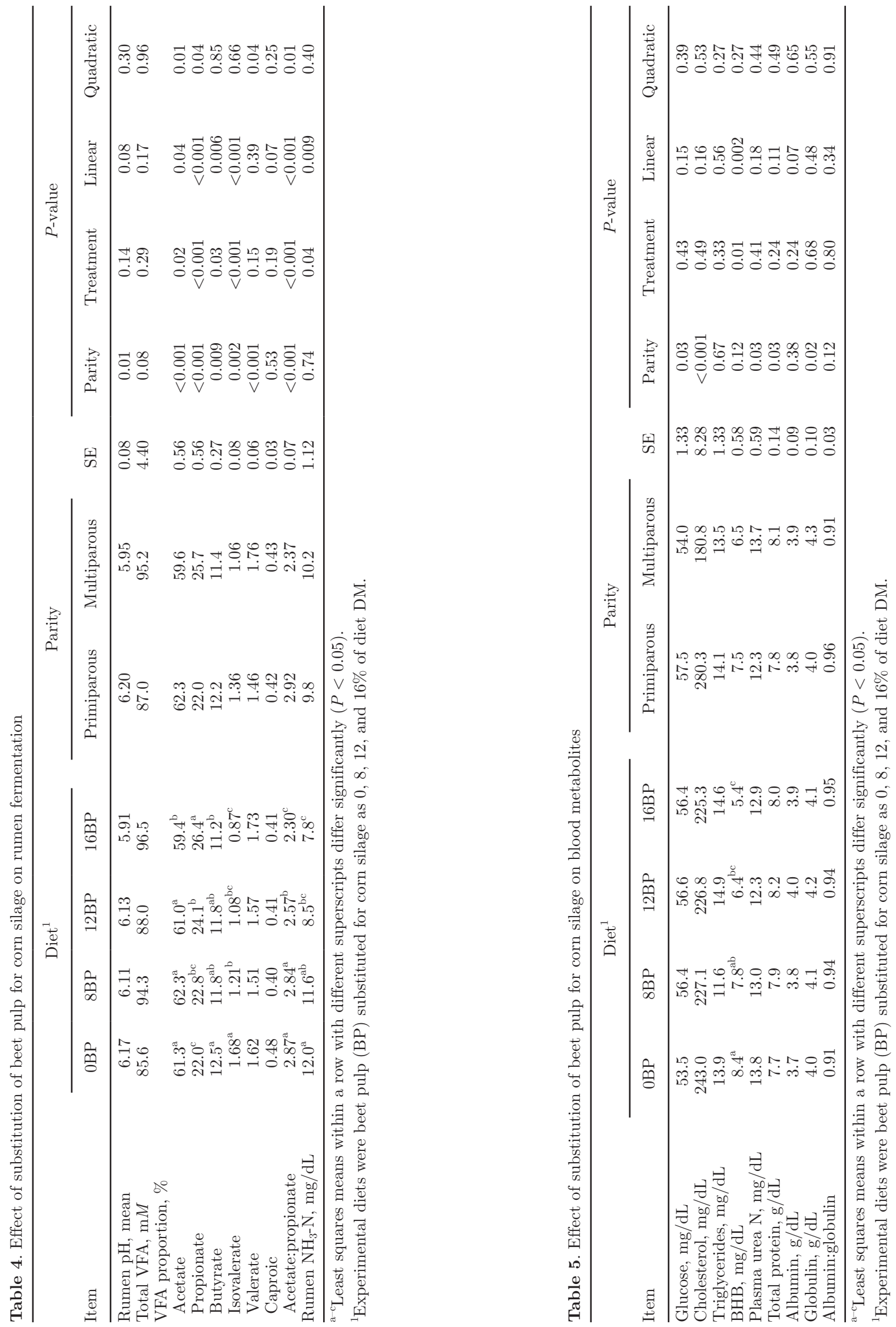
est inclusion level of beet pulp $(P<0.01)$, following the trend for fat and protein concentration. The MUN concentration decreased linearly $(P<0.01)$ and was lower for $12 \mathrm{BP}$ and 16BP than for control $(P=0.02)$. Primiparous cows produced more FCM $(P=0.02)$, ECM $(P=0.01)$, SCM $(P<0.01)$, and lactose $(P$ $<0.01)$ than multiparous cows, but milk component concentrations were similar for both groups. The interaction between parity and treatment was significant for milk production and milk protein production. The average milk production for $0 \mathrm{BP}, 8 \mathrm{BP}, 12 \mathrm{BP}$, and $16 \mathrm{BP}$ diets was $39.8,40.0,41.5$, and $42.0 \mathrm{~kg} / \mathrm{d}$ for primiparous cows, respectively, and $37.2,38.6,40.4$, and 37.3 $\mathrm{kg} / \mathrm{d}$ for multiparous cows, respectively. The average milk protein production for $0 \mathrm{BP}, 8 \mathrm{BP}, 12 \mathrm{BP}$, and $16 \mathrm{BP}$ treatments was $1.17,1.22,1.28$, and $1.32 \mathrm{~kg} / \mathrm{d}$ for primiparous cows, respectively, and 1.15, 1.21, 1.24, and $1.16 \mathrm{~kg} / \mathrm{d}$ for multiparous cows, respectively.

The feed efficiency parameters milk yield/DMI, FCM/DMI, ECM/DMI, and SCM/DMI were not affected by diet. Cows produced an average of $1.67 \mathrm{~kg}$ of ECM $/ \mathrm{kg}$ of feed DM. Primiparous cows were more efficient than multiparous cows, producing 1.74 versus $1.60 \mathrm{~kg}$ of ECM $/ \mathrm{kg}$ of feed DM $(P<0.01)$. Substitution of beet pulp for corn silage quadratically increased BW $(P=0.03)$ but had no effect on BCS, back fat thickness, or changes in BW. We observed a tendency $(P=0.07)$ for cows fed 12BP to have greater BCS and back fat thickness than the others. Multiparous cows had greater BW, BCS, and back fat thickness than primiparous cows $(P<0.01)$, but parity did not affect changes in body reserves.

\section{DISCUSSION}

Studying the effects of decreasing forage proportion in the diet by replacing corn silage with beet pulp under heat stress conditions is relevant to dairy farming in dry, hot climatic conditions, when the cost of forage is high and cows are heat-stressed. However, few studies have been conducted under these conditions, which limits the comparison of our results with the literature. Climatic data indicated that mild heat stress conditions occurred during the entire study, with the THI exceeding 68 units each day (Armstrong, 1994; Bernabucci et al., 2010). Heat stress can affect DMI and energy requirements, and can initiate oxidative reactions that affect nutrient digestion, blood metabolism, and milk production (Kargar et al., 2015). We speculated that responses might be affected by parity, because cows with lower parity (i.e., primiparous) have lower body mass, resulting in lower total heat production.

The lack of effect of dietary treatment on DMI was not expected. Indeed, because the rate of ruminal NDF digestibility of beet pulp is faster (less rumen-filling effect) than that of corn silage, we expected an increment in DMI with increasing beet pulp level. For example, greater DMI has been observed when soy hulls replaced forage (Miron et al., 2010). However, our study was distinct from that of Miron et al. (2010) because of lactation stage (Allen et al., 2009); the mid-lactation cows used in our study may not have experienced a filling effect to the same extent as the early-lactation cows used by Miron et al. (2010). In mid-lactation cows, high levels of propionate and its oxidation in liver can be a limiting factor for DMI (Allen et al., 2009; Nasrollahi et al., 2012). Moreover, the conditions of heat stress experienced in the current study may have metabolically prevented cows from eating more, despite physical space in the rumen.

The similar DMI between multi- and primiparous cows was not expected. Multiparous cows in the current study had lower mean rumen $\mathrm{pH}$, a greater concentration of propionate, and greater total VFA concentration than primiparous cows, factors that may have decreased DMI (Allen et al., 2009) to a level similar to that of primiparous cows. One possible explanation for the lower rumen $\mathrm{pH}$ in multiparous cow might be that they were more sensitive to heat stress (Holter et al., 1997). Greater sensitivity of multiparous cows to ambient temperature might have led to less time chewing and lower saliva production (Karimi et al., 2015).

The lack of effect of replacing corn silage with beet pulp on nutrient digestibility was also not expected. Previous studies with other NFFS have reported improvements in apparent digestibility (Miron et al. 2010; Mohammadzadeh et al., 2014). Similar apparent digestibilities for all diets was consistent with the lack of treatment effect on total VFA concentration in the rumen. The decrease in molar percentage of acetate and butyrate and the concurrent increase in propionate concentration was consistent with the well-documented effects of decreasing the forage NDF and physically effective NDF content of diets, along with increasing the rate of rumen NDF digestibility (Bhatti and Firkins, 1995; Allen, 1997). The small particle size of beet pulp compared with corn silage would likely have decreased chewing time (Penner et al., 2009, Zhang et al., 2010; Mohammadzadeh et al., 2014) and saliva production (Bailey, 1961), consistent with the observed change in acetate:propionate ratio (Zhang et al., 2010).

The improvement in milk yield with increasing NFFS was consistent with other studies that used other sources of NFFS to replace forage (Boddugari et al., 2001; Penner et al., 2009; Zhang et al., 2010). However, in those studies, improvements in milk production were related to the increased nutrient digestibility of NFFS, but that was not the case in this study, because 
SUBSTITUTION OF SHREDDED BEET PULP FOR CORN SILAGE

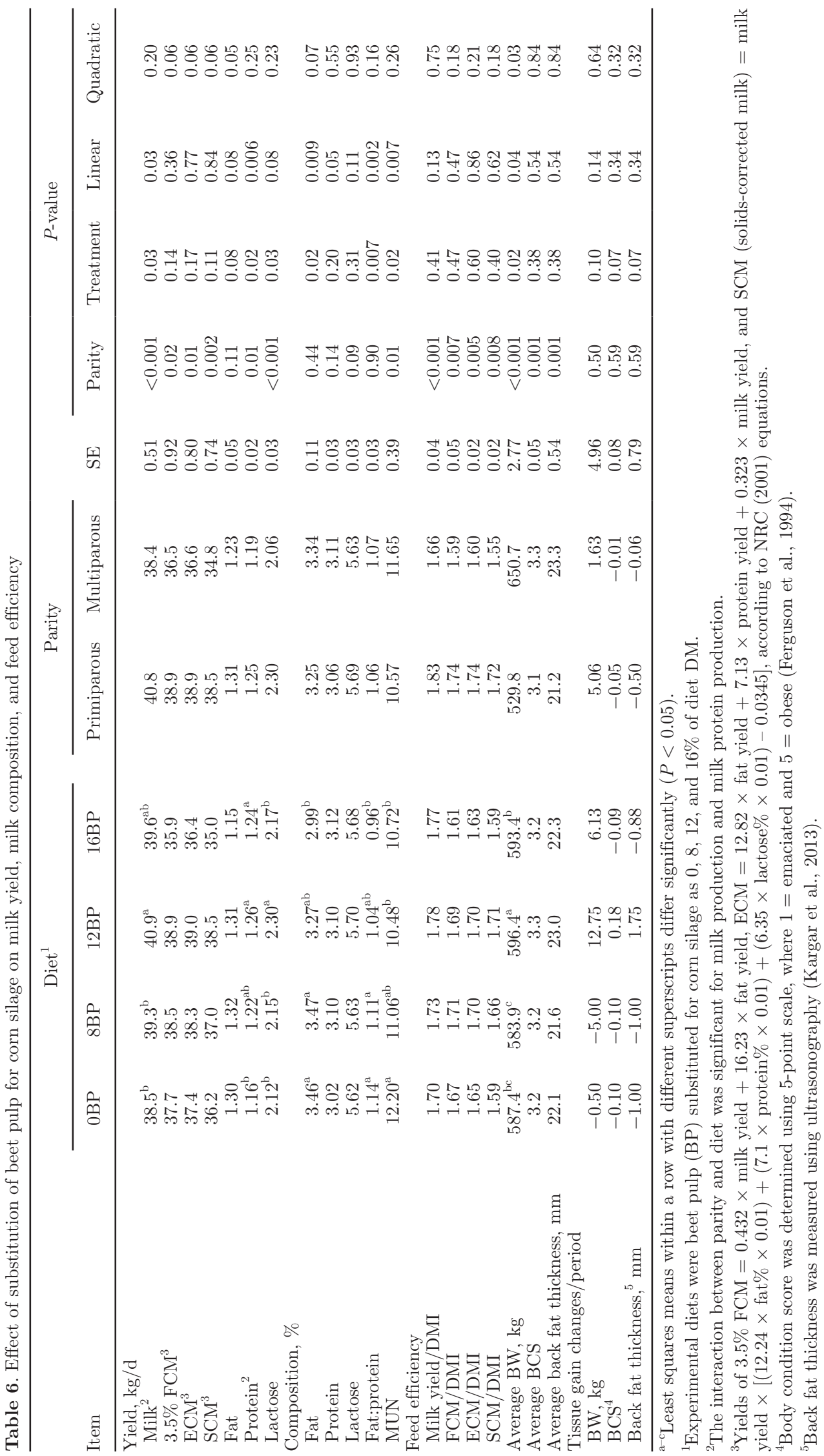


digestibility was not affected by treatment. Although $\mathrm{NE}_{\mathrm{L}}$ intake increased numerically as beet pulp was substituted for corn silage, the increase was not large enough to account for the differences in milk production among diets. It is possible that the increase in milk production was due to a change in efficiency of nitrogen utilization. Indeed, increasing levels of beet pulp increased the dietary concentration of NDICP, an indicator of rumen-undegradable protein (Fox et al., 2004). Increased intake of NDICP would have accounted for the considerable decrease in $\mathrm{NH}_{3}-\mathrm{N}$ concentration in rumen fluid and the corresponding decrease in MUN. These changes indicate improved protein utilization. Another possible explanation could relate to the rumen fermentation profile, in which propionate concentration increased and acetate decreased with increasing beet pulp in the diet. Propionate is the main glucogenic precursor for milk synthesis (Van Soest, 1994; Ramanzin et al., 1997).

The increase in milk protein percentage by replacing corn silage with beet pulp was not expected. The increased milk protein percentage suggests that the inclusion of beet pulp may have increased metabolizable protein flow to the small intestine. The Cornell Net Carbohydrate and Protein System analysis revealed that beet pulp had higher rumen-undegradable CP content than immature corn silage. Further investigation is required to determine the effects of including beet pulp as a forage substitute on milk protein production with reference to ruminal and intestinal $\mathrm{CP}$ digestibility and flow of metabolizable protein to the small intestine.

The highest concentration of beet pulp ( $16 \%$ of diet DM) decreased milk fat percentage. Non-forage fiber sources are high in NDF content, but because of their small particle size they have low physical effectiveness for stimulating chewing activity (Clark and Armentano, 1993; Zhang et al., 2010; Mohammadzadeh et al., 2014). Partial replacement of forage with NFFS often reduces milk fat concentration (Weidner and Grant, 1994; Boddugari et al., 2001; Penner et al., 2009; Zhang et al., 2010) by decreasing chewing time and rumen $\mathrm{pH}$ (Boddugari et al., 2001; Harvatine et al., 2002). Low milk fat content is often used as an indicator of rumen health and may indicate that the level of physically effective NDF in the 16BP diet was inadequate (Zebeli et al., 2012).

Primiparous cows had greater 3.5\% FCM, ECM, and SCM than multiparous cows, a finding that has not been commonly observed previously (Maekawa et al., 2002; Kowsar et al., 2008). This result may further confirm our conclusion that primiparous cows were more tolerant of heat stress in this study. The net result of greater heat stress for multiparous cows led to similar
DMI, less milk production, and poorer feed efficiency in multiparous cows than in primiparous cows.

The study revealed that feeding beet pulp up to $12 \%$ of the dietary DM in place of corn silage improved the performance of mid-lactating dairy cows without unfavorable effects on rumen health for a period of $21 \mathrm{~d}$. The results might be interesting for farmers in places where the cost of beet pulp is relatively similar to, and sometimes even lower than, the cost of forages (i.e., alfalfa hay and corn silage). The results indicate that feeding beet pulp can be considered as an alternative for reducing the cost of feed and replacing forage sources when they are in short supply.

\section{CONCLUSIONS}

Under conditions of heat stress, replacing corn silage with beet pulp did not affect nutrient intake, digestibility, blood metabolites, or rumen $\mathrm{pH}$. However, rumen propionate concentration increased and acetate concentration decreased, leading to an improvement in milk production and milk protein percentage. The optimal inclusion rate of beet pulp was $12 \%$ of dietary DM, because a further increase caused milk fat depression. Primiparous cows had greater milk production, greater rumen $\mathrm{pH}$, and similar nutrient intake and digestibility compared with multiparous cows. Overall, the study indicated that corn silage can be replaced with beet pulp up to $12 \%$ of dietary DM without negative effects on the productivity of mid-lactating dairy cows under conditions of heat stress for a short period of time.

\section{ACKNOWLEDGMENTS}

The authors thank Isfahan University of Technology (Isfahan, Iran) for partially funding this research and providing facilities. Appreciation is extended to staff at the Lavark farm and the research and teaching unit (Isfahan University of Technology, Isfahan, Iran), and to Mohsen Babashahi, Mojtaba Arjmandfar, HamidReza Dadkhah, Mostafa Heydari, Mohammad Rahimi, Milad Ahmadi, Ali-Reza Ghafouri, Ali Kahyani, and Hamid Khoshouei (Isfahan University of Technology, Isfahan, Iran) and M. Safahani Langroodi and M. Khosravi for their help in conducting this experiment. We also acknowledge the help of several students from the Isfahan University of Technology completing course requirements.

\section{REFERENCES}

Allen, M. S. 1997. Relationship between fermentation acid production in the rumen and the requirement for physically effective fiber. J. Dairy Sci. 80:1447-1462. 
Allen, M. S., B. J. Bradford, and M. Oba. 2009. Board-invited review: The hepatic oxidation theory of the control of feed intake and its application to ruminants. J. Anim. Sci. 87:3317-3334.

AOAC International. 2002. Official Methods of Analysis. 17th ed. AOAC International, Arlington, VA.

Armstrong, D. V. 1994. Heat stress interaction with shade and cooling. J. Dairy Sci. 77:2044-2050.

Bailey, C. B. 1961. Saliva secretion and its relation to feeding in cattle. 3 . The rate of secretion of mixed saliva in the cow during eating, with an estimate of the magnitude of the total daily secretion of mixed saliva. Br. J. Nutr. 15:443-451.

Baumgard, L. H., and R. P. Rhoads. 2012. Ruminant production and responses to heat stress. J. Anim. Sci. 90:1855-1865.

Bernabucci, U., N. Lacetera, L. H. Baumgard, R. P. Rhoads, B. Ronchi, and A. Nardone. 2010. Metabolic and hormonal acclimation to heat stress in domesticated ruminants. Animal 4:1167-1183.

Bhatti, S. A., and J. L. Firkins. 1995. Kinetics of hydration and functional specific gravity fibrous feed by-products. J. Anim. Sci. 73:1449-1458.

Boddugari, K., R. J. Grant, R. Stock, and M. Lewis. 2001. Maximal replacement of forage and concentrate with a new wet corn milling product for lactating dairy cows. J. Dairy Sci. 84:873-884.

Broderick, G. A., and J. H. Kang. 1980. Automated simultaneous determination of ammonia and total amino-acids in ruminal fluid and in vitro media. J. Dairy Sci. 63:64-75.

Clark, P. W., and L. E. Armentano. 1993. Effectiveness of neutral detergent fiber in whole cottonseed and dried distillers grains compared with alfalfa haylage. J. Dairy Sci. 76:2644-2650.

Ferguson, J. D., D. T. Galligan, and N. Thomsen. 1994. Principal descriptors of body condition score in Holstein cows. J. Dairy Sci. 77:2695-2703.

Fox, D. G., L. O. Tedeschi, T. P. Tylutki, J. B. Russell, M. E. Van Amburgh, L. E. Chase, A. N. Pell, and T. R. Overton. 2004. The Cornell Net Carbohydrate and Protein System model for evaluating herd nutrition and nutrient excretion. Anim. Feed Sci. Technol. 112:29-78.

Fox, D. G., T. P. Tylutki, K. J. Czymmek, C. N. Rasmussen, and V. M. Durbal. 2000. Development and application of the Cornell University nutrient management planning system. Pages 167-179 in Proc. Cornell Nutr. Conf. Feed Manuf., Rochester, NY. Cornell Univ., Ithaca, NY.

Harvatine, D. I., J. L. Firkins, and M. L. Eastridge. 2002. Whole linted cottonseed as a forage substitute fed with ground or steam-flaked corn: digestibility and performance. J. Dairy Sci. 85:1976-1987.

Holter, J. B., J. W. West, and M. L. McGilliard. 1997. Predicting ad libitum dry matter intake and yield of Holstein cows. J. Dairy Sci. 80:2188-2199.

Iranian Council of Animal Care. 1995. Guide to the Care and Use of Experimental Animals. Vol. 1. Isfahan University of Technology, Isfahan, Iran.

Kargar, S., G. R. Ghorbani, V. Fievez, and D. J. Schingoethe. 2015. Performance, bioenergetic status, and indicators of oxidative stress of environmentally heat-loaded Holstein cows in response to diets inducing milk fat depression. J. Dairy Sci. 98:4772-4784.

Kargar, S., G. R. Ghorbani, M. Khorvash, E. Kamalian, and D. J. Schingoethe. 2013. Dietary grain source and oil supplement: Feeding behavior and lactational performance of Holstein cows. Livest. Sci. 157:162-172.

Karimi, M. T., G. R. Ghorbani, S. Kargar, and J. K. Drackley. 2015. Late-gestation heat stress abatement on performance and behavior of Holstein dairy cows. J. Dairy Sci. 98:6865-6875.

Kowsar, R., G. R. Ghorbani, M. Alikhani, M. Khorvash, and A. Nikkhah. 2008. Corn silage partially replacing short alfalfa hay to optimize forage use in total mixed rations for lactating cows. J. Dairy Sci. 91:4755-4764.

Licitra, G., T. M. Hernandez, and P. J. Van Soest. 1996. Standardization of procedures for nitrogen fractionation of ruminant feeds. Anim. Feed Sci. Technol. 57:347-358.

Liu, Z. L., P. Chen, J. M. Li, S. B. Lin, D. M. Wang, L. P. Zhu, and D. P. Yang. 2008. Conjugated linoleic acids (CLA) moderate negative responses of heat-stressed cows. Livest. Sci. 118:255-261.
Maekawa, M., K. A. Beauchemin, and D. A. Christensen. 2002. Chewing activity, saliva production, and ruminal $\mathrm{pH}$ of primiparous and multiparous lactating dairy cows. J. Dairy Sci. 85:1176-1182.

Marounek, M., S. Bartos, and P. Brezina. 1985. Factors influencing the production of volatile fatty acids from hemicellulose, pectin and starch by mixed culture of rumen microorganisms. Z. Tierphysiol. Tierernahr. Futtermittelkd. 53:50-58.

Miron, J., G. Adin, R. Solomon, M. Nikbachat, A. Zenou, E. Yosef, A. Brosh, A. Shabtay, A. Asher, H. Gacitua, M. Kaim, S. Yaacobi, Y. Portnik, and S. J. Mabjeesh. 2010. Effects of feeding cows in early lactation with soy hulls as partial forage replacement on heat production, retained energy and performance. Anim. Feed Sci. Technol. 155:9-17.

Mohammadzadeh, H., K. Rezayazdi, and A. Nikkhah. 2014. Effects of inclusion of graded amounts of soya bean hulls on feed intake, chewing activity and nutrient digestibility in dairy cows. J. Anim. Physiol. Anim. Nutr. (Berl.) 98:476-482.

Moore, C. E., J. K. Kay, R. J. Collier, M. J. VanBaale, and L. H. Baumgard. 2005. Effect of supplemental conjugated linoleic acids on heat-stressed Brown Swiss and Holstein cows. J. Dairy Sci. 88:1732-1740.

Naderi, N. 2014. Effects of substitution of dried sugar beet pulp for corn silage on performance and chewing behavior of high producing dairy cows. MSc Thesis. Isfahan University of Technology, Isfahan, Iran.

Nasrollahi, S. M., M. Khorvash, G. R. Ghorbani, A. Teimouri-Yansari, A. Zali, and Q. Zebeli. 2012. Grain fermentability and marginal changes in forage particle size modulated digestive processes, and nutrient intake in dairy cows. Animal 6:1237-1245.

Nordlund, K. V., and E. F. Garrett. 1994. Rumenocentesis: A technique for the diagnosis of subacute rumen acidosis in dairy herds. Bovine Pract. 28:109-112.

NRC. 1971. A Guide to Environmental Research on Animals. Natl. Acad. Sci., Washington, DC.

NRC. 2001. Nutrient Requirements of Dairy Cattle. 7th rev. ed. Natl. Acad. Sci., Washington, DC.

Penner, G. B., P. Yu, and D. A. Christensen. 2009. Effects of replacing forage or concentrates with wet or dry distillers' grains on the productivity and chewing activity of dairy cattle. Anim. Feed Sci. Technol. 153:1-10.

Ramanzin, M., L. Bailoni, S. Schiavon, and G. Bittante. 1997. Effect of monensin on milk production and efficiency of dairy cows fed two diets differing in forage to concentrate ratios. J. Dairy Sci. 80:1136-1142.

SAS Institute. 2003. SAS User's Guide. Version 9.1. SAS Institute Inc., Cary, NC.

Van Keulen, V., and B. H. Young. 1977. Evaluation of acid-insoluble ash as natural marker in ruminant digestibility studies. J. Anim. Sci. 26:119-135.

Van Soest, P. J. 1994. Nutritional Ecology of the Ruminant. 2th ed. Cornell Univ., Ithaca, NY

Van Soest, P. J., J. B. Robertson, and B. A. Lewis. 1991. Methods for dietary fiber, neutral detergent fiber, and nonstarch polysaccharides in relation to animal nutrition. J. Dairy Sci. 74:3583-3597.

Weidner, S. J., and R. J. Grant. 1994. Altered ruminal mat consistency by high percentages of soybean hulls fed to lactating dairy cows. J. Dairy Sci. 77:522-532.

Wilson, R. C., T. R. Overton, and J. H. Clark. 1998. Effects of Yucca shidigera extract and soluble protein on performance of cows and concentrations of urea nitrogen in plasma and milk. J. Dairy Sci. 81:1022-1027.

Zebeli, Q., J. R. Aschenbach, M. Tafaj, J. Boguhn, B. N. Ametaj, and W. Drochner. 2012. Invited review: Role of physically effective fiber and estimation of dietary fiber adequacy in high-producing dairy cattle. J. Dairy Sci. 95:1041-1056.

Zhang, S. Z., G. B. Penner, M. Abdelqader, and M. Oba. 2010. Effects of feeding alfalfa hay on chewing, rumen $\mathrm{pH}$, and milk fat concentration of dairy cows fed wheat dried distillers grains with solubles as a partial substitute for barley silage. J. Dairy Sci. 93:3243-3252. 